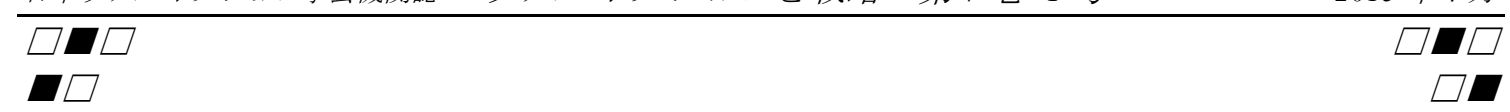

〈大会シンポジウム2014年 11月 22日: 講演要旨、於: 東洋大学白山キャンパス〉

\title{
金融ネットワークのシステミックリスク分析
}

\author{
西口 健二
}

日本総合研究所 理事

1. はじめに

本稿では、リーマンショックの前後から 強く認識されるようになってきた金融ネッ トワークのシステミックリスクについて考 察する。

まず、筆者自身の経験を通じて、日本の 金融機関のリスクについて振り返る。90 年 代から 2000 年代初めはバブル後の不良債 権の問題に金融機関は悪戦苦闘した。また、 複雑化するデリバティブ取引のリスク管理 でも邦銀はキャッチアップに苦労すること となる。そして、2000 年代半ばになって、 サブプライムや証券化の問題からリーマン ショック・金融危機の時代のリスク管理と なる。20 数年間、リスクのネタは絶えるこ となく生まれてきたと言える。

特に数年前からの金融や経済を取り巻く 事象の特徴は、本日のタイトルともなって いる「金融ネットワークのシステミックリ スク」の急拡大にあると考えられ、このリ スクについて、モデル化を含めて、解説す るのが本稿の狙いだ。

ある意味で、個々の金融機関経営とマク ロの間のリスクを分析しようという試みで もあり、ようやく少しずつ結果で出てきて いる状況である。

\section{2. システミックリスクの高まり}

金融商品の複雑化と金融システムの多層 化のもとで、金融リスクが飛躍的に拡大し
ているが、そのメカニズムとして、まず市 場リスクや信用リスクのテールリスクが実 現することになる。これはサブプライムや 証券化商品で顕在化したように、「分散」の 仮説の崩れに起因することが典型であり、 その当時の格付機関や規制にも誤算があっ たところである。

さらに、金融ネットワークのシステミッ クリスクとでもいうべきものが、その本質 として伸長する。これには二つの側面があ り、(1)市場型金融における連鎖リスク、(2) 伝統的金融における実体経済との間でおこ る循環（スパイラル）リスク、である。こ の新たなリスクこそが、金融危機の前後か ら急激に拡大してきていて、その対応が求 められてきているリスクだ。

\section{3. マクロプルーデンスの視点}

ここで、システミックリスクに関連して、 最近話題になることの多いマクロプルーデ ンスについて触れる。このマクロプルーデ ンスは、大変わかりにくい概念であるが、 平成 25 年 9 月に金融庁より公表された、金 融モニタリング基本方針には、「個々の金融 機関にとって合理的な行動であっても、多 くの金融機関が同様の行動をとることによ って、予期せぬ影響を経済全体に及ぼし、 それが金融機関経営にも影響を及ぼしうる こと（金融機関の行動とマクロ経済・市場 との相互連関性)」と記され、マクロプルー 
デンスの視点が示されている。

こういう視点の重要性を明らかにして理 論的な出発点となった論文 [5]を紹介する。 これまでの投資理論によれば、分散投資を することにより個別金融機関のリスクは減 じることになる。ところが、[5]では、個別 金融機関が分散投資をしてリスクを減じて も、同じ投資行動を金融機関がとれば、金 融システム全体としてリスクが増加するこ とがあることを示した。言い換えれば、個 別の金融機関を一律に規制しても金融シス テム全体のリスクが増えうるということで あり、個々の最適の合成が全体最適ではな いというディレンマを抱えることになる。

\section{4. システミックリスク把握のモデル化}

では、この「金融ネットワークのシステ ミックリスク」の特徵をどう分析するかで あるか、そのひとつのモデル化を、[6][ 7] に基づき紹介寸る。ここが、本稿の中心と なるところだ。

モデルは、銀行間取引を表すネットワー クと、各銀行が保有する投融資のポートフ オリオが、それぞれどんな特性を持つとき に、この「金融ネットワーク」がどのよう なシステミックリスクを持つかを説明する ことを目的とする。

それぞれをもう少し詳しく説明する。ま ず、銀行間取引のネットワークだが、これ は、銀行（行数は $\mathrm{N}$ とする）が平均的に銀 行間で資金を取っている行数 $\kappa$ と、資産額 上位 5 行が銀行間資金取引の総額に占める 割合をR5 として、これらを満たす銀行間取 引のネットワークをランダムに生成する。

なお、ここでは簡単のため、銀行の自己 資本比率 $\gamma$ と銀行間資金放出額の資産に対
する比率 $\theta$ は、どの銀行でも同じとする。

次に、銀行が保有する投融資のポートフ オリオだが、これは仮定として価值変動が 独立な $\mathrm{M}$ 個の資産からなり、各銀行の完全 均等分散からのずれを表す指標 $\varepsilon$ と、銀行 間でどの程度多様な投資になっているかの 指標 $\delta$ として、これらを満たす投融資のポ ートフォリオをやはりランダムに生成する。 このような銀行間取引のネットワークと 投融資のポートフォリオのそれぞれを 1 サ ンプルとして生成させて、その各サンプル で資産価值を変動させる。その結果、ある 銀行において自己資本を上回る損失がでる と倒産する。これを初期ショックとよぶ。

次に、初期ショックにより倒産した銀行 に資金を放出していた銀行はそれが回収で きなくなるがここではそれが全額回収でき なくなる仮定のもとで、次にその放出元の 銀行が倒産することがある。そしてさらに 連鎖することがあり、金融システム全体に 波及する。こうして最終的に倒産する銀行 数の初期ショックでの倒産銀行数に対する 比率を一定の信頼水準（ここでは 99\%）で 算定した A がこの金融ネットワークのシス テミックリスクを表す指数と考えられる。

そこで、この A が金融ネットワークの違 いによりどのような特性を持つかであるが、 文献[ 6 ]によれば以下の結果が得られる。 (1)銀行間で投融資ポートフォリオが類似す ると（ $\delta$ が小さくなると）、連鎖倒産リスク が大きくなる。

(2)投融資ポートフオリオが完全均等分散に 近いと（ $\varepsilon$ が小さくなると）、連鎖倒産リス クが大きくなる傾向がある。

(3)銀行間取引が上位行に集中すると（R5 が 大きくなると)、連鎖倒産リスクが大きい。 
(4)銀行間取引の関係を持つ銀行の組が増え ると（ $\kappa$ が大きくなると）、連鎖倒産リスク が大きい。

また、同文献によると、

(5)日本・米国・英国の各金融システムは異 なるにも拘らず、システミックリスクの指 数であるA はほぼ同じ 2.3 から 2.7 程度とな る(図 1 で(a)が日本、(b)が米国、(c)が英国)。

図 1 （出所：文献 [6 ])

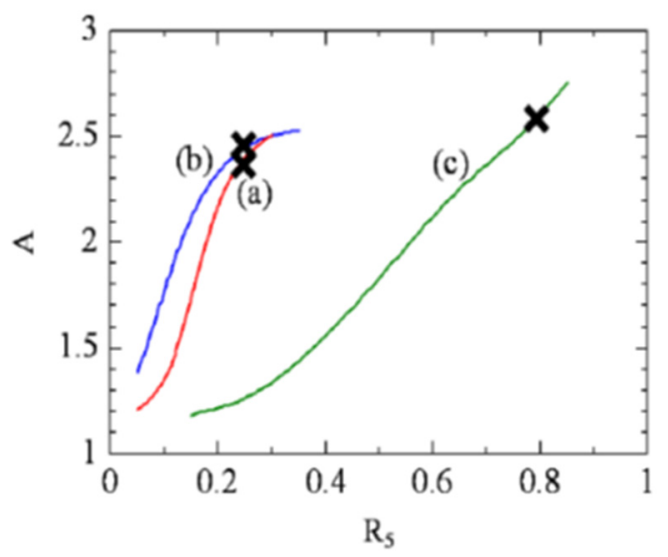

6)また、G-SIBS への資本サーチャージが提 唱されているが、 $2.5 \%$ 程度のサーチャージ を資産額上位 25 行程度に行うことが相応 の効果をもたらす (図 2 で、 $\mathrm{N}=500$ 行中で、 資本サーチャージが（a）全くない、（b）上 位 5 行、（c）上位 25 行、（d）上位 50 行）。

図 2（出所：文献[6 ]）

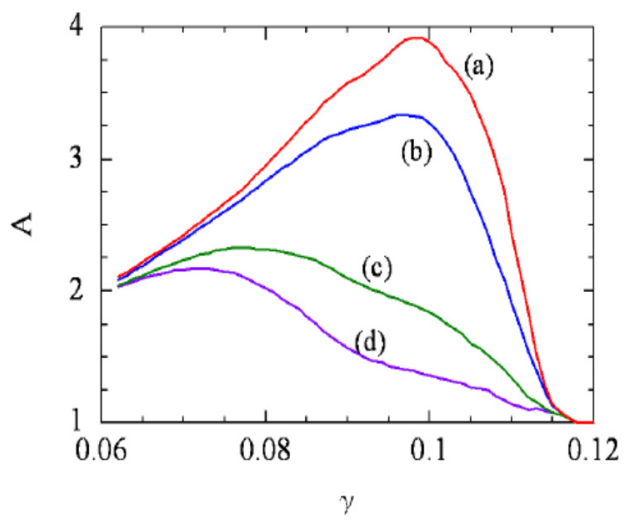

\section{CDS による信用リスク移転}

次に、前節のモデルを使っての事例研究 として、CDS によるリスク移転が金融シス テムにもたらす影響と金融システムのリス ク指標の導出について解説する。

各金融機関は、自らの信用リスク管理の ためにCDS (Credit default swaps)等を用い て銀行間取引の信用リスク移転を行うこと があるが、これにより金融システム全体の リスクが軽減されるかを分析する。前節の モデルにおいて、第三の銀行に CDS 契約で 定義された倒産や債務不履行といった事象 が起こると、プロテクションの販売銀行が プロテクションの購入銀行に損失が賄われ るとし、以下を仮定する : ( i )す心゙ての銀行 間貸出についてプロテクションを購入、( ii ) プロテクションの販売銀行は資産額上位 5 銀行、(iii)どの銀行からプロテクションを購 入するかはランダム、(iv) リスク移転後の追 加の銀行間貸出を実施可（比率 f)。

このもとで、文献 $[7$ ]によれば以下の結論 が得られる。

(1)金融システム全体のリスクはCDS 等を用 いて信用リスク移転をしても変わらない (図 3 で（d）と（e）が概ね一致)。

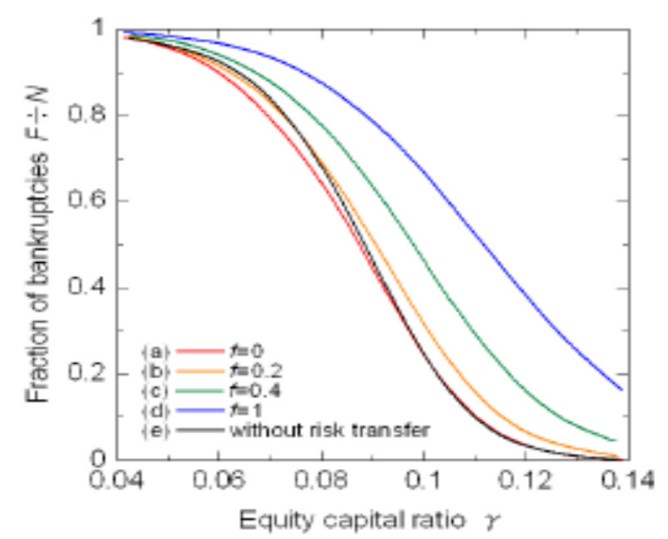


(2)各銀行によりリスク移転がなされたこと により計算されるバーゼル規制の自己資本 比率、すなわち、リスク調整がなされた指 標は金融システムのリスクを表さない。む しろ、リスク調整がされないシンプルなレ バレッジ比率の方が金融システムのリスク を表すことがわかる（図 4 は自己資本比率 の換算を表し、図 5 ではその換算された自 己資本比率 $\gamma \mathrm{s}$ とレバレッジ比率 1 のグラ フが概ね一致することがわかる)。

図 4（出所 : 文献 7 ]）

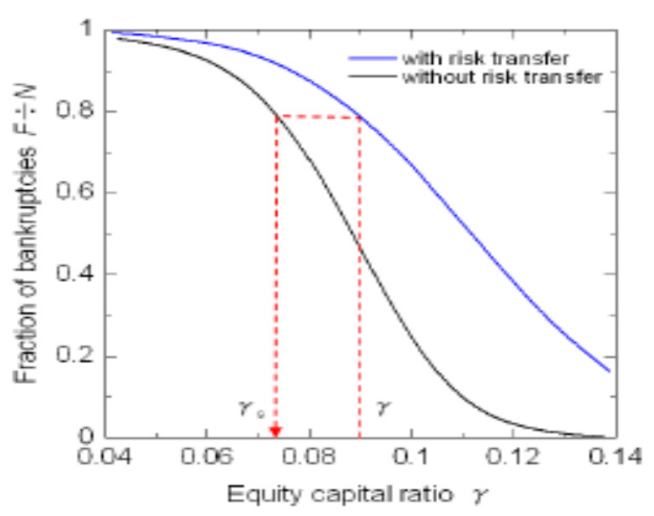

図 5 (出所 : 文献 $[7]$ )

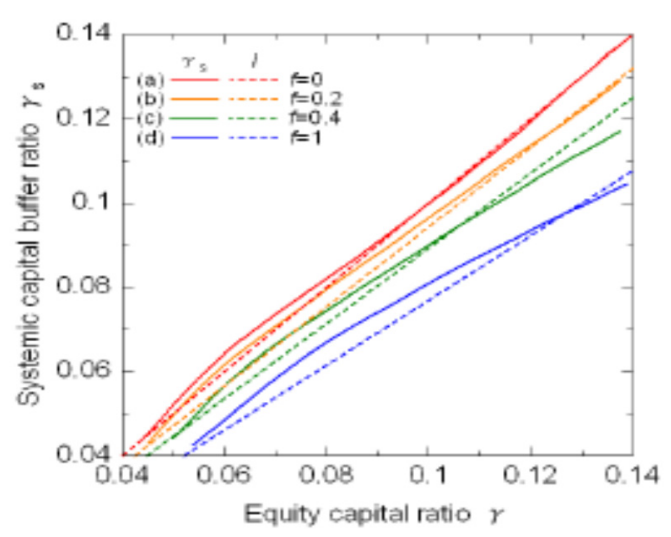

\section{6. システミックリスク分析の今後}

最後にこの枠組みの今後の展開を 3 点紹 介する。
まず 1 点目は、銀行の大型合併が世界的 に金融危機の後で進んできているが、今後、 大規模な合併があると金融ネットワークの 構造が大きく変わり、効率性が増す一方、 システミックが高まると言われている。

特に、同じ規模となる合併でも、ネット ワーク構造の変化の仕方が異なり、システ ミックリスクの変動は異なる。そこで、ど ういう合併であればリスクが増すかを適切 に評価することが金融機関経営と金融規制 監督の両面から重要であり、このモデルの 応用が期待される。

また、2 点目は、昨今話題になることが 多いシャドーバンキンについてだ。これら が金融ネットワークに介在する場合、どの 程度システミックリスクに影響を与えるか、 というのも大きなテーマとなっており、こ こにも本モデルによる分析が望まれる。

具体的には、自己資本が劣後する金融機 関がネットワーク内に内在する場合にどの 程度、システミックリスクが増大寸るかを 把握しようとする試みであり、金融機関経 営や監督の両面から重要である。特に、自 己資本が劣後する金融機関の割合が、どの 程度にまでなるとシステミックリスクが飛 躍的に増加するかを把握することはシステ ムの効率性と安定のバランスをみるために も必要性高く、このモデルを用いた分析が 期待される領域だ。

そして 3 点目は、新興国を含めた金融ネ ットワークのモデル化だ。先進国間と新興 国間では複層ネットワークになっていると 考えられ、先進国の投融資先となっている 新興国で問題が発現した際に、先進国やさ らに世界の金融システムに連鎖するリスク を適切に把握していくことが、グローバル 
な資金移動が活発となってきている現下に おいて、金融機関・監督の双方にとり極め て重要と言える。こういった分析において も本稿で紹介したアプローチが応用可能と 考えられ今後の展開が望まれる。

\section{7. 終わりにーシステミック VaRに向けー}

これまで述べてきたように、現在の金融 が抱える課題というには、金融ネットワー クのシステミックリスクにかかわることが 極めて多い

そこで、本稿の取組のひとつの目標とな るのが、「システミックリスクの定点観測」 である。各時点の金融ネットワークが一定 期間後にどの程度のシステミックリスクを 示現させる可能性があるか、ある意味でシ ステミックリスク V a R とでもいえるもの の計測だ。

もう少し詳しく述べると、現時点のネッ トワークが今後変化して被る連鎖の最大值 (“システミックリスク值”）を

・一定期間後（1 年等）

・一定信頼水準（99\%等）

で評価するという考え方だ、さらに、各金 融機関が当該ネットワークの中でどれだけ 連鎖に巻き込まれるかを把握して、各金融 機関別のシステミックリスク值もこの中で 算定しようというものだ。

このような形で、システミックリスクが 数值で常時評価可能となれば、金融機関も 監督も、金融バブルにしっかり備えること ができるようになるわけで、市場リスク、 信用リスク、オペレーショナルリスクの次 に位置付けられるリスク管理モデルとなる ものだ。

もちろんまだ解決すべきことは多い。何
よりもそのためには現時点のネットワーク 構造や、過去のネットワークの変化につい ての観測データが必要となる。そのために は、民間の金融機関と各国の金融監督当局 が協力して体制を整備していくことが不可 久であり、金融の最重要課題のひとつだ。

ここまでご説明してきたように今やシス テミックリスクの把握は夢物語ではなくな ってきている。そして、世界的にもこの領 域は、この 1,2 年、大いに進展してきて おり、今後とも大いに進展が予想される。 本稿で、その一端がご紹介できていれば幸 いである。

\section{【文献】}

[1] 西口健二：「リスク管理を中心とする金 融機関の将来展望」、財務省フィナンシャ ル・レビュー 2010 年第 3 号、通巻 101 号 [2] 日本銀行:「金融システムレポート」2011 年 10 月

[3] 日本総合研究所編 :「金融システムの将 来像」、金融財政事情研究会、2010 年 10 月 [4] Adrian \& Brunnermeier: : 「CoVaR $\rfloor$ 、 May 27, 2009

[5] N.Beale et al: Individual versus systemic risk and Regulator's Dilemma」Proceedings of National Academy of Sciences, August 2, 2011

[6] 前野義晴・西口健二・森永聡・松島宏和: 「ANWSER モデルで計測した銀行の連鎖 倒産リスク」、証券アナリストジャーナル、 2013 年 6 月号

[7] 前野義晴・西口健二・森永聡・松島宏和：

$\lceil$ Impact of credit default swaps on financial contagion $\rfloor$ IEEE Computational Intelligence for Financial Engineering \&Economics, London, 2014 年 3 月 